\title{
Vertical-Flow Constructed Wetlands in Cooperating with Oxidation Ponds for High Concentrated COD and BOD Pig-Slaughterhouse Wastewater Treatment System at Suphanburi-Provincial Municipality
}

\author{
Piyaporn Pitaktunsakul ${ }^{1}$, Kasem Chunkao ${ }^{1}$, Narouchit Dampin ${ }^{1} \&$ Satreethai Poommai ${ }^{1}$ \\ ${ }^{1}$ Department of Environmental Science, Faculty of Environment, Kasetart University, Bangkok, Thailand \\ Correspondence: Piyaporn Pitaktunsakul, Department of Environmental Science, Faculty of Environment, \\ Kasetart University, Bangkok, Thailand. Tel: 66-81-684-3284.
}

Received: December 10, 2014

Accepted: November 25, 2014

Online Published: July 30, 2015

doi:10.5539/mas.v9n8p371

URL: http://dx.doi.org/10.5539/mas.v9n8p371

\begin{abstract}
Oxidation Pond (OP) as engineering tool is generally used for treating the pig slaughterhouse wastewater which normally contains high concentration of COD and BOD in effluent. Unfortunately, it cannot reduce the organic substance (blood, hairs, grease, meats, solid dunks and some contaminants) from pig slaughtering areas under the 2-consecutive oxidation ponds by producing the minimum values of COD $151.92 \mathrm{mg} / \mathrm{L}$, BOD $79.14 \mathrm{mg} / \mathrm{L}$, coliform bacteria $2.6 \times 10^{-5} \mathrm{MPN} / 100 \mathrm{~mL}$, and fecal bacteria $1.5 \times 10^{-5} \mathrm{MPN} / 100 \mathrm{~mL}$ but all of them above the standard values. After treating the effluent by VFCW-Typha from the 2-consecutive oxidation ponds, the results found COD $90.92 \mathrm{mg} / \mathrm{L}$, BOD $31.67 \mathrm{mg} / \mathrm{L}$, coliform bacteria $1.5 \times 10^{-4} \mathrm{MPN} / 100 \mathrm{~mL}$ and fecal bacteria $2.0 \times 10^{-3}$ MPN/100 mL which were almost above the standard values. It is noted that the modification of 2-m consecutive ponds to 4-m consecutive ponds in cooperating the prolongation of VFCW-Typha length instead of 30 meters to 40-50 meters, width 3-5 meters, and still keeping 1-m depth would be enough to support the pig-slaughterhouse wastewater treatment system.

Summarily speaking, the experimental results have been brought to say that the Oxidation Pond as the engineering tool could not be applicable in slaughterhouse wastewater treatment that containing high concentration COD and BOD from slaughtering and dissecting activities.
\end{abstract}

Keywords: vertical-flow constructed wetland, oxidation pond, wastewater treatment, pig-slaughterhouse

\section{Introduction}

Wastewater treatment in Thailand are normally engineering devices which are seemingly designed for on-site establishment exactly at the point sources. The Royal Thai Government (RTG) on behalf of DOPC-MONRE (2010) has paid the annual budget more or less 50,000 M Baht to construct the community wastewater treatment system at every municipal and local administration, and being accomplished not later than 2015. Additionally, the government issued laws to obligate all industrial factories, housing estates, high buildings, hotels and shopping centers as to treat their wastewater before releasing to the public water sources (MOPH 1998, DOPC-MONRE (2010), and DIW-MOI 1996). In general, the engineering devices are used for wastewater treatment system in case of Filtration, Floatation, Skimming, Sedimentation, Asa Grit Chamber, Precipitation, Chemical Coagulation, Neutralization, Oxidation Pond (OP), Activated Sludge (AS), Stabilization Pond (SP), Aerated Pond (AP), Aerated Lagoon (AL), Bio Ditch Filter (BDF), Trickling Filter (TF), Upflow Anaerobic Sludge Blanket (UASB), Rotating Bio Contractor (RBC), Phytoremediation/Phytoextraction, Carbon Adsorption (CA), Activated Carbon Absorption (ACA), Reverse Osmosis (RO), Ion Exchange (IE) and some modified equipments to decrease the specific pollutants. (Metcalf and Eddy 1979, Ramsey et al 2013, Borja et al 1998, Metcalfe et al 1979). Unfortunately, the failure of implementing wastewater treatment has been found all the country (Faerge et al 2001, Berkun 2005, Faulkner et al 2000, Padgett 1975 ,Streeter and Phelps 1925, Tyagi et al 1999, Hosetti and Frost 1995), especially the settlement of factories and cities along the riverbanks as the serious point sources for causing stream pollution (Streeter and Phelps 1925, Tyagi et al 1999, Faulkner et al 2000, Berkun 2005, Pattamapitoon 2013). Even though the RTG still spent a lot if budget but the stream pollution has been spread out in every river. It cannot be put into words why wastewater pollution in worse condition almost every river. The basic mistakes might come from too high expensive engineering wastewater 
treatment tools, costly electricity, and intensive care for effective function during mechanical operation, This is the reason why the engineering tools for wastewater treatment from any sources cannot meet the requirement of the standards in all parts of the country.

Moreover, the slaughterhouse is among those point sources of effluent as the same as industrial factory, communities, households, municipals, transportation, poultry farms, and cultivating areas, in which the public water sources have been intruded by their treated wastewater from those ineffective engineering tools.

In Thailand, there are many reports concerning with pork consumption, approximately $30 \mathrm{~kg} / \mathrm{person} / \mathrm{year}$ (each pig weight more or less $120 \mathrm{~kg}$ ) which brought to slaughter about 12 million hogs/year (approximately 33,000 hogs/day) for Thai people. Consequently, the water use for washing and cleaning in the slaughtering processes inside the slaughterhouses about 3.3 MCM/day around the country. In the same manner, each pig slaughterhouse produces organic waste in terms of Biochemical Oxygen Demand (BOD) up to $1,200 \mathrm{mg} / \mathrm{L}$ to be treated before draining into the public water sources (such as streams, canals, rivers), in order to keep water sources avoiding the stream pollution after receiving its treated wastewater. The Royal Thai Government has declared the Water Quality Standard Laws for slaughterhouse effluent since 1960 and having one key issue on establishing the Oxidation Pond which is the engineering tool for wastewater treatment. Unfortunately, this technology seems blur to apply in Thai style for pig slaughtering techniques which are needed not only pork meet but also blood and another organs as well. Keeping hogs in pigpen before killing would be another reason why slaughterhouse wastewater was comprised of concentrated Chemical Oxygen Demand (COD), Biochemical Oxygen Demand (BOD), Total Dissolved Solid (TDS), and Suspended Solid (SS) than they were found in the developed country. This characteristics of slaughterhouse wastewater have been shown the evidence that the engineering-tool Oxidation Pond could not meet the target to have effluent under standard value (Tritt and Schuchardt 1992, Borja 1995, Masse and Masse $2000 \mathrm{a}$ and b, Cao and Mehrvar 2011, Othman et al 2013, and Palatri et al 2011).

It can make the conclusion here that the Oxidation Pond for wastewater treatment tool might not be applicable for such high concentration of slaughterhouse wastewater for Thai-slaughtering style. In general, the anaerobic digestion is usually introduced in order to decrease the high concentration down to the suitable concentration level before transferring through the Oxidation Pond to obtain the effluent equal or less than standard value (for example, $120 \mathrm{mg} / \mathrm{L}$ for Chemical Oxygen Demand (COD), $20 \mathrm{mg} / \mathrm{L}$ for Biochemical Oxygen Demand (BOD), $100 \mathrm{mg} / \mathrm{L}$ for Total Kjeldahl Nitrogen (TKN). Unfortunately, the device for producing an effect to decrease high concentration of pig slaughterhouse wastewater is more expensive and complicated to install along with the existing Oxidation Pond as seen in every municipal. For the tropical climate like Thailand, the vertical-flow constructed wetlands (VFCW) are proposed to retreat the OP effluent as directly drained out from the ready-installed Oxidation Pond, the previous research results were satisfactory and applicable to all parts of the country (LERD 1999).

In principles, wetland is the swamp unit area which works together among soils, aquatic plants and organic wastewater for assimilating balance of inorganic-nutrient storage, and nutrient absorption for aquatic plant growth as well as the remediation of toxic chemicals. In another points, the bacterial organic digestion is naturally in both sub-soils and wastewater over soil surface by obtaining the oxygen as energy supplying through the processes of thermo-osmosis, and thermo-siphon from the atmosphere and also from phytoplankton and algae photosynthesis. (Deubigh and Raumann 1952, Grosse 1989, Mirmov and Belyakava 1982, Grofse and Bauch 1991, Bearman 1957,Ameth and Stchimair 2001).The products of bacterial organic digesting process as mentioned are exactly identified as plant nutrients and some toxic chemicals as accumulated in soils for growing submerged aquatic plants (such as typha, cyperus) and dispersing in treated wastewater for growing phytoplankton (Suchkov et al 2010, Luangsoonton 2010, Stottmeister et al 2003, Keddy 2010, Maine 2006, Juwarkar et al 1995, Khan et al 2009, Boyd 1970, Jenssen et al 1993, Hammer 1989, Hammer and Bastian 1989, Ahn and Mitsch 2002, Kayser and Hunst 2005, Cui et al 2010). The balancing condition is really needed to harvest the submerged aquatic plants by clear cutting of the zero-growth rate of the oldest plants with leaving the stem about $30-\mathrm{cm}$ height, and to consume the herbivore fishestogetherwith zero-growth rate of biggest size (LERD 1999 and 2012, Sklarz et al 2009, Molle et al 2008). The said concept has been shown in success of organic wastewater treatment under the biological processing principles through both the vertical and horizontal flow constructed wetlands (VFCW and HFCW) as evidenced from the previous researches (Soroko 2007, Cauillard et al 1989, Kayser and Hunst 2005, Ahn and Mitsch 2002, Hammer and Bastian 1989, Hammer 1989, Boyd 1970, Khan et al 2009, Juwarkar et al 1995, Stottmeister et al 2003, Cui et al 2010). The wastewater treatment efficiencies were varied from $85 \%$ to $95 \%$ for COD, BOD, TDS, SS, DOC, DOP, DON, NH3-N, color, coliform and fecal bacteria; $80 \%$ to $90 \%$ for sulfate, TKN, EC, alkalinity, acidity, and organic compounds (Boyd 1970, Khan et al 2009, Juwarkar et al 1995, Main et al 2006, Nopparatanaporn 1992, Molle et al 2008, 
Sklarz et al 2009). The previous researches were also indicated that the most effective efficiency of small vertical flow constructed wetlands could be applicable on the BOD concentration more or less $200 \mathrm{mg} / \mathrm{L}$ which found in effluent values of Oxidation Ponds. Such indicated effluent values cannot be released into the public water sources without any exempts. In order to sovereign the problem, the coopering Oxidation Ponds and VFCW is proposed to treat high concentrated COD and BOD of pig slaughterhouse wastewater by following the previous researches such as LERD 1999, Soroko 2007, Molle et al 2008 and Sklarz et al 2009).

\section{Methods and Procedures}

\subsection{Location of Project Site}

Project site for applying the VFCW units for pretreatment to high concentration of organic matters in slaughterhouse wastewater is localized inside the solid waste management land area at AmphoeMuang municipal of Suphanburi province (population about 60,000 persons) in tropical climate (annual rainfall 1,200 - 1,400 mm, average temperature $32{ }^{\circ} \mathrm{C}$ with ranging been $25-39^{\circ} \mathrm{C}$ ) on the upper part of perennially Suphanburi river (about $720 \mathrm{~km}$. length of S-shaped watercourse), as called only the upstream of Thachin river, in westerly Bangkok about 110-km distance as shown in Figure 1. In reality, Suphanburi river flows from Chainat headwater and connecting by watergate with Chainat diversion-dam reservoir which can supply water flowing through Suphanburi rivet all year round without even long-time water shortage. This situation can make Suphanburi province all-time green with paddy rice fields and vegetables growing, and also follow-up livestock farming, particularly pig, poultry, and cow.

Those activities have been induced more plat nutrients in stream water as the products of bacterial organic digesting from releasing the organic wastes into the stream water. This is why the glory morning vegetables growing can be done on the Thachin river water surface from Suphanburi to Nakhon Pathom provinces, appraising more than 500 million Baht per annum. Besides, there have been a lot of households settling along on both sides of Suphanburi river as the same as the food industrial factories, paddy rice, cropping areas and sightseeing tours would be another point sources. Moreover, thousands of acres are in use for growing rice and another economic crops but the chemical fertilizers and pesticides have been applied for increasing the agricultural products. Due to high fertility of Thachin river water as obtained from bacterial organic digestion, there are a lot of water surface areas on about on both riversides that have been used for growing morning glory vegetables all years round and producing yields more than 100 tons per annum. Such cropping activity could enhance to decrease a lot of nitrogen and phosphorus content in Thachin river water and another elements.

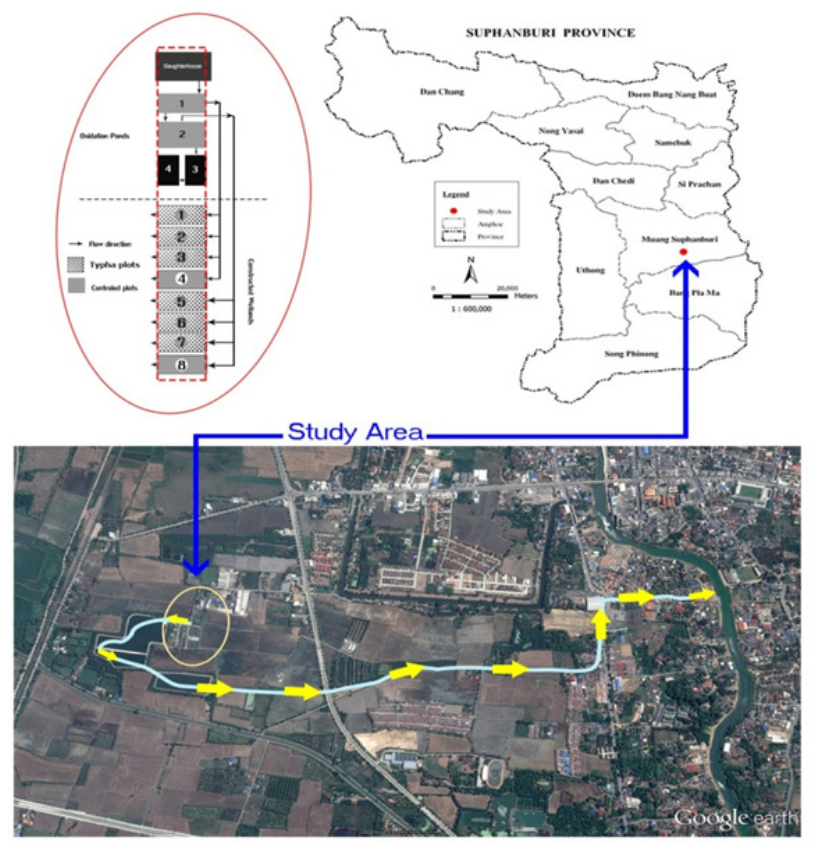

Figure1. Location of slaughterhouse the Suphanburi municipal AmphurMuang, Suphanburi province, including office building, pigpen, slaughtering and cleaning areas, wastewater drainage system, and four-sectional ponds of Oxidation Disc as engineering technology for slaughterhouse wastewater treatment as well as eight vertical flow constructed wetlands. 


\subsection{Suphanburi Slaughterhouse Establishment}

The slaughterhouse is located inside the occupied area (1.5 sq.km) for managing solid waste and MuangSuphanburi municipal wastewater treatment system as indicated in Figures 1 and 2. In fact, the study site is composed of Oxidation Disc (OD) and eight vertical flow constructed wetlands (VFCW) which are surrounded by the sanitary landfills and neighboring fermented-stool boxes and lagoons (oxidation ponds) for treating Suphanburi municipal wastewater about $120 \mathrm{cu} . \mathrm{m}$./day as obtained from population of about 60,000 persons' activities. Anyway, the wastewater from pig slaughterhouse would be expected to transfer directly or indirectly to Thachin river one way or another.

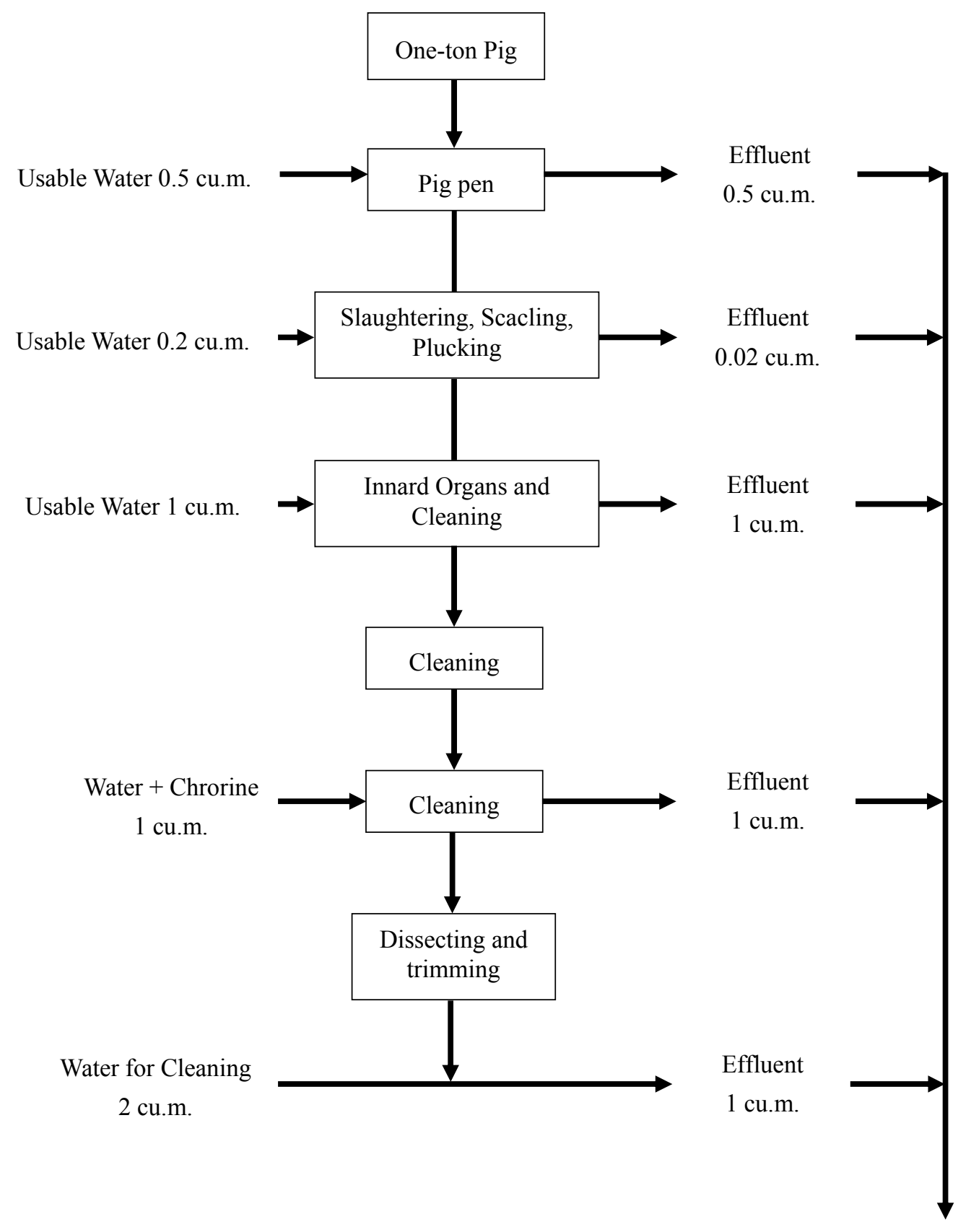

Total 4.52 cu.m.

Figure 2. Layout of water use for Hog slaughtering and dissecting of Suphanburi slaughterhouse at AmphoeMuang municipal, Suphanburi province 


\subsection{Establishment of Vertical Flow Constructed Wetland (VFCW)}

Eight VFCW units (30-m long, 3-m wide, and 0.75-m deep) with typha planting (25x25-cm spacing) were constructed on line of the 8-consecutive sectional ponds for second treatment to the effluent of Oxidation Pond (Figure 3). Usually, the slaughterhouse wastewater is received the slaughterhouse wastewater with high concentrated organic matters approximately between 6 - 10 cubic meters per days for $24-32$ hogs $(4.52$ cu.m.water for one tone of hog) as shown in Figure 2. Consequently, this amount of slaughterhouse wastewater will be drained into the first of the OD four-sectional sectional ponds to the second, third and fourth between 2:00 - 6:00 am for the 6-day slaughtering of a week (except Buddhist holyday). However, the past records of water quality measurement from all 4-sectional ponds were found higher standard values of BOD $(200 \mathrm{mg} / \mathrm{L})$ and COD $(120 \mathrm{mg} / \mathrm{L})$ in which they was selected for taking the slaughtering wastewater for 8 vertical flow constructed wetlands as second treatment in order to meet the effluent standard requirement before releasing to the public water sources.

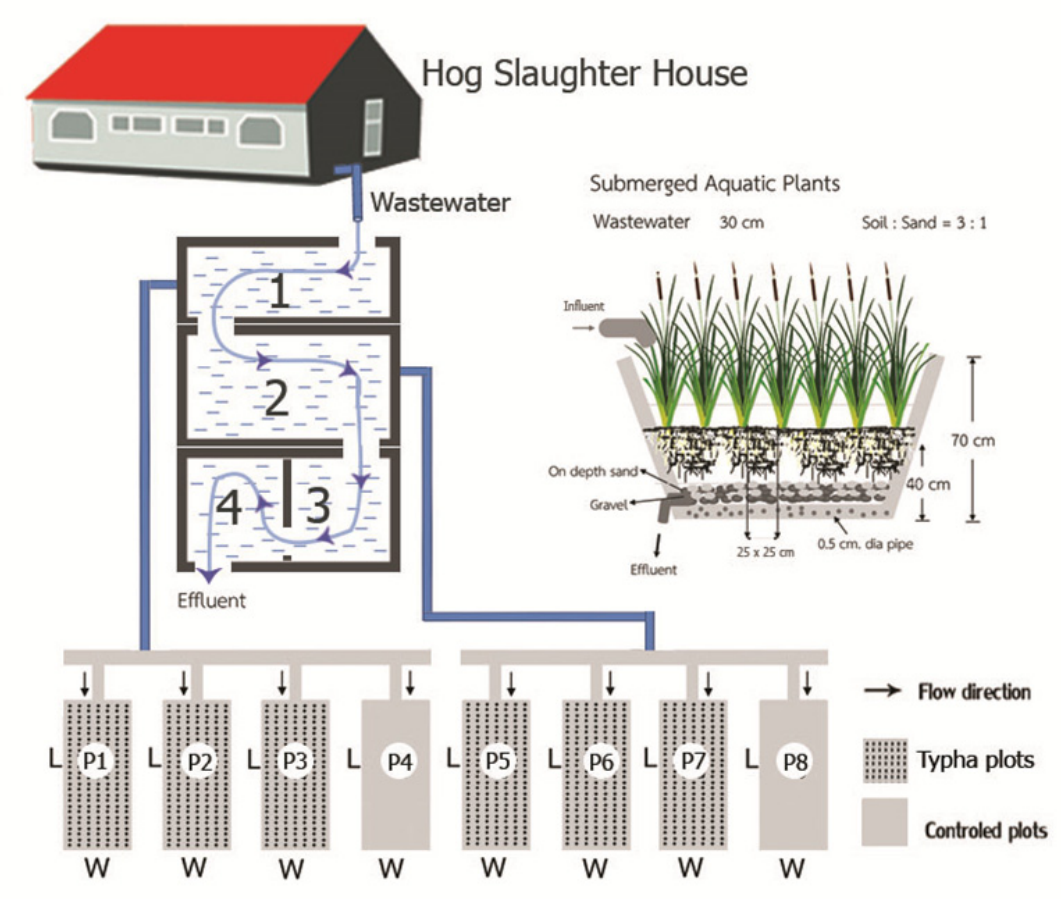

Figure 3. Hypothetical characteristics of Oxidation Pond (OP) together with X-section and longitudinal highlighting of small vertical flow constructed wetlands(VFCW) as grown typha (25-spacing) to retreat the effluent from the higher concentration sectional OP pond 2 for producing an effective slaughterhouse wastewater in Suphanburi province

\subsection{Contaminants of Slaughterhouse Wastewater}

Living hogs are transported from the swine farms to put in pigpen inside the slaughterhouse for a few days before killing them. Surely, the solid waste from pigpen floor is necessary to wash off the pig dunks into the sectional OP pond 1. A great number of blood and some organic materials as well as grease has to wash off by $4.52 \mathrm{cu} . \mathrm{m}$./one-ton pig to became the slaughterhouse wastewater into the sectional OP pond 1 as shown in Figure 2. Actually, the slaughtering pigs are prohibited on important days in Buddhism, such a Buddhist holy days, beginning and ending Buddhist Lent, Songkran, (Thai new year), new year (international), Magha Bucha Days, VisaghaBucha Day, and the middle of the lunar month (DIW-MOI 1996).Totally, they come together to 60 days with no organic wastewater from slaughtering houses. As stated in former times, the water use for pig slaughtering can be calculated more or less $120 \mathrm{cu} . \mathrm{m} . / \mathrm{d}$, as become the slaughterhouse wastewater for about 100 cu.m. forfulling OP treatment system (DOPC-MONRE 1998).

\subsection{Techniques for Encouraging Organic Digestion Processes}

The slaughterhouse wastewater was pumped from sectional OP pond 2 to distribute for all VFCW units together 
with alternating between stagnating storage for 5 days (to provide the occurrence of bacterial organic digestion processes and soil filtration by vertical flowing) and releasing the treated wastewater for the next 2 days (to drain out treated wastewater) until the the cutting period of growing aquatic plants with $25-\mathrm{cm}$ spacing in which the visible light will be induced to water surface as used for photosynthesis while rapid evapotranspiration occurs for oxygen diffusion through the water surface by thermo-siphon processing. Nevertheless, the air from the atmosphere will be brought through the thermo-osmosis process by the oxygen-producing photosynthesis in spongy cells (aerenchyma cells) of very young leaf that belonging to aquatic plants. The growing aquatic plants (such as typha, cyperus,etc.) plays vital role in absorbing plant nutrients and toxic chemicals under the phytoremediation process for keeping nutrients balancing in soils.

\subsection{Wastewater Sample Collection and Water Quality Analysis}

As mentioned beforehand, the VFCW treatment efficiency for slaughterhouse wastewater of OD ponds 1 and 2 was intentionally proposed to take part in economizing operation cost in relation to the toxicant effluent elimination after releasing to the public water sources. In order to meet the target, the treated wastewater from OP ponds 1 and 2 were applied for second treatment by two-consecutive sets of 3 VFCW (including 1 control in each set). At the same time, the typha aquatic plants were grown in all six VFCW units (except 2 control units) along with $25 \times 25-\mathrm{cm}$ spacing. Flowing slaughtering wastewater at depth of $30 \mathrm{~cm}$ above VFCW beds for 5-day stagnation and 2-day releasing until the planting typha met the matured stage, about the twelfth weeks and/or flowering period. The matured typha plants were cut for determining biomass before analyzing some chemical composition.

Wastewater samples were collected before transferring into the small VFCW units and on the seventh days during releasing for analyzing COD, BOD, TDS, SS, EC, DO,Temperature, $\mathrm{pH}$, coliform bacteria in order to determine the existing slaughterhouse wastewater and treatment efficiency of VFCW units for the second treatment of the effluent from OD effluent which are shown the BOD and COD concentration normally higher than standard values. Practically, there are six VFCW-Typha units (plus another two control units each) in size of 3-m width, 30-m length and 1-m depth at AmphoeMuang municipal in Suphanburi province as located in the western part of Thailand about $110 \mathrm{~km}$ from Bangkok. The hog slaughterhouse wastewater was pumped from the sectional ponds 1 and 2 into two sets of one for control and three for vertical flow constructed wetlands at the level of 30-cm depth from the bottom; the sectional pond 1 for the first set and the sectional pond 2 for the second. Consecutively, the hog slaughterhouse wastewater was alternatively treated with the stagnated storage for 5 days and releasing for 2 days to the public watercourse. The said operation was continually taken in time after time until typha growing up to the harvesting stage at the age about 12-week period. During planting and maturing age, the effluent as obtained from the vertical flow through soil, sand, and gravel was sampled at the ended-pipe outlet every 7 days in order to analyze COD and BOD as well as the concerned factors,I.e., DO, TDS, TSS, TKN, total and Ortho phosphorus, EC, alkalinity, $\mathrm{pH}$ and coliform bacteria. At the same manner, the hight growth of typha was measured every 7 days on one spot at the middle and another four spots at the conners of the vertical flow constructed wetlands for determining the maximum height-growth age (mature age) in which the aquatic typha should be functioned with the most effectiveness for wastewater treatment through the VFCW units. Immediately after harvesting the typha leaves had to sample randomly for determining its biomass and also the accumulated nutrients of soils at $15-\mathrm{cm}$ soils to extract the chemicals of both the toxicants and plant nutrients as well. The decreases of COD and BOD concentration as well as their related quality indexes such as DO, TDS, TKN, Total P, Ortho P, EC, Temperature, and $\mathrm{pH}$ were analyzed under the standard methods as recommended by APHA,AWWA,WEF (2005), and also determining soil nutrients by Black et al (1965)

\section{Results and Discussion}

\subsection{Nature of Pig Slaughterhouse Wastewater}

As mentioned before, the Oxidation Pond System with 4-sectional ponds is well known among environmental engineers and technologists as well as the the environmental administrators for pig slaughterhouse wastewater treatment (Palatri et al 2011, Othman et al 2013, Cao and Mehrvar 2011). Regrettably, it was found less efficiency for decreasing high concentrated COD and BOD of slaughterhouse wastewater. Accordance with such results, the primarily experiment was conducted by taking the role of 24, 27, and 32 pigs (DIW-MOI 1996) from slaughtering and dissecting in relation to water-use quantity and wastewater quality. according with experimental results, the $\mathrm{OP}$ effluent quality indicators $\mathrm{COD}$ and $\mathrm{BOD}$ were over standard values while the others are opposite as illustrated in Table1. 
Table 1. Quantity and quality of wastewater (effluent) from hog slaughtering and dissecting activities of Suphanburi municipal slaughterhouse through the 4-sectional ponds of Oxidation Pond

\begin{tabular}{|c|c|c|c|c|c|c|c|}
\hline \multirow[t]{2}{*}{ No. } & \multirow[t]{2}{*}{ Water Quality Indicators } & \multirow[t]{2}{*}{ Unit } & \multicolumn{4}{|c|}{ Number of Hogs } & \multirow[t]{2}{*}{ Standard Values } \\
\hline & & & 24 & 27 & 32 & Average & \\
\hline 1 & COD & $\mathrm{mg} / 1$ & $1,450.9$ & $1,424.9$ & $1,403.8$ & $1,426.3$ & 120 \\
\hline 2 & BOD & $\mathrm{mg} / 1$ & 34.7 & 36.7 & 30.6 & 34.03 & 20 \\
\hline 3 & TDS & $\mathrm{mg} / 1$ & 254.7 & 315.3 & 215.0 & 261.7 & 3,000 \\
\hline 4 & $\mathrm{EC}$ & $\mu \mathrm{s} / 1$ & 506.3 & 631.3 & 453.3 & 530.3 & 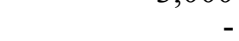 \\
\hline 5 & DO & $\mathrm{mg} / 1$ & 1.9 & 3.5 & 3.6 & 3.0 & 4.0 \\
\hline 6 & Alkalinity & $\mathrm{mg} / 1$ & 286.0 & 392.7 & 297.3 & 325.3 & , \\
\hline 7 & $\mathrm{pH}$ & & $\begin{array}{r}200 \\
7.8\end{array}$ & 7.9 & 7.9 & $\begin{array}{r}7.9 \\
7.9\end{array}$ & 5.5 \\
\hline 8 & Temperature & ${ }^{\circ} \mathrm{C}$ & 31.8 & 37.4 & 35.5 & 34.6 & 40.0 \\
\hline 9 & Wastewater Quantity & cu.m. & 5.95 & 7.3 & 9.8 & - & 10.0 \\
\hline
\end{tabular}

It is surprising to point out that the COD values were high up to $1,450.9 \mathrm{mg} / \mathrm{L}$ for 24 slaughtering pigs, $1,424.9$ $\mathrm{mg} / \mathrm{L}$ for 27 pigs, 1,403.8 mg/L for $32 \mathrm{pigs}$ and averaged 1,426.30 mg/L DOPC-MONRE (2010)because the higher ions could be obtained from antibiotics and growth stimulants in blood and liquid-solid wastes during and after pig slaughtering. Consequently,such rapid organic digestion rate has theoretically paid significant role in lowering the effluent quality as indicated in BOD values down to $34.7 \mathrm{mg} / \mathrm{L}$ for 24 pigs killing, $34.7 \mathrm{mg} / \mathrm{L}$ for 27 pigs, $30.6 \mathrm{mg} / \mathrm{L}$ for 32 pigs, and averaged $34.3 \mathrm{mg} / \mathrm{L}$. In other words, the rapid decrease of BOD can make increasing COD during transferring the slaughterhouse wastewater through not only killing points but also flowing from the pond 1 through ponds 2, 3, and 4 in form of effluent of Oxidation Pond (Masse and Masse 2000 a and b, Borja 1995, Tritt and Schuchard 1992, Borja et al 1998). Also, killing diseases after pig slaughtering activities with chlorine solution as obligated by Public Health lawsn (MOPH 1998) declaring would be another cause of drastic increasing COD in OD effluent (Couillaed et al 1989).

Table 2. Averaged values of slaughterhouse wastewater quality from OD sectional ponds 1 and 2 before and after draining into VFCW-Typha and VFCW-Control units at pig slaughterhouse in Suphanburi province

\begin{tabular}{|c|c|c|c|c|c|c|c|c|c|c|c|c|c|c|c|}
\hline \multirow[t]{5}{*}{ No. } & \multirow[t]{5}{*}{ Item/Unit } & \multicolumn{14}{|c|}{ Averaged Values of Wastewater Quality } \\
\hline & & \multirow[t]{2}{*}{$\mathrm{COD}$} & \multirow[t]{2}{*}{ BOD } & \multirow[t]{2}{*}{ TDS } & \multirow[t]{2}{*}{ TKN } & \multirow[t]{2}{*}{$\mathrm{NH}_{3}-\mathrm{N}$} & \multirow{2}{*}{$\begin{array}{c}\text { Total } \\
\mathrm{P} \\
\end{array}$} & \multirow{2}{*}{$\begin{array}{c}\text { Ortho } \\
\mathrm{P}\end{array}$} & \multirow[t]{2}{*}{ DO } & \multirow[t]{2}{*}{ Alkalinity } & \multirow[t]{2}{*}{$\mathrm{EC}$} & \multirow[t]{2}{*}{$\mathrm{pH}$} & \multirow[t]{2}{*}{ Temp. } & \multirow{2}{*}{$\begin{array}{c}\text { Coliform } \\
\text { Bacteria } \\
\end{array}$} & \multirow{2}{*}{$\begin{array}{l}\text { Fecal } \\
\text { Bacteri }\end{array}$} \\
\hline & & & & & & & & & & & & & & & \\
\hline & & $\mathrm{mg} / \mathrm{l}$ & $\mathrm{mg} / 1$ & $\mathrm{mg} / 1$ & $\mathrm{mg} / 1$ & $\mathrm{mg} / 1$ & $\mathrm{mg} / 1$ & $\mathrm{mg} / 1$ & $\mathrm{mg} / \mathrm{l}$ & $\mathrm{mg} / 1$ & $\mu \mathrm{s} / \mathrm{cm}$ & & ${ }^{\circ} \mathrm{C}$ & MPN/ & MPN/ \\
\hline & & & & & & & & & & & & & & $100 \mathrm{ml}$ & $100 \mathrm{ml}$ \\
\hline After & 1.VFCW-Typha & & & & & & & & & & & & & & \\
\hline pond & Before & 328.80 & 181.98 & 441.98 & 56.03 & 32.55 & 12.38 & 11.01 & 0.50 & 431.00 & 846.00 & 6.88 & 31.40 & $2.1 \times 10^{6}$ & $1.1 \times 10^{6}$ \\
\hline \multirow[t]{8}{*}{1} & After & 129.19 & 57.67 & 310.13 & 29.71 & 19.42 & 10.78 & 9.47 & 1.52 & 396.67 & 554.73 & 7.55 & 27.92 & $2.9 \times 10^{4}$ & $2.0 \times 10^{4}$ \\
\hline & Efficiency & 59 & 70 & 30 & 47 & 40 & 13 & 13 & - & 8 & 36 & - & 11 & 96 & 98 \\
\hline & $(\%)$ & & & & & & & & & & & & & & \\
\hline & \multicolumn{15}{|l|}{ 2.VFCW-Control } \\
\hline & Before & 328.80 & 181.98 & 441.98 & 56.03 & 32.55 & 12.38 & 11.01 & 0.50 & 431.00 & 846.00 & 6.88 & 31.40 & $2.6 \times 10^{6}$ & $1.9 \times 10^{6}$ \\
\hline & After & 174.68 & 51.60 & 212.33 & 26.98 & 18.29 & 11.15 & 10.45 & 4.00 & 379.20 & 495.20 & 7.73 & 29.32 & $4.0 \times 10^{4}$ & $2.0 \times 10^{4}$ \\
\hline & Efficiency & 44 & 66 & 52 & 52 & 43 & 10 & 15 & - & 12 & 42 & - & 6 & 95 & 99 \\
\hline & $(\%)$ & & & & & & & & & & & & & & \\
\hline After & \multicolumn{15}{|l|}{ 1.VFCW-Typha } \\
\hline pond & Before & 151.92 & 79.14 & 271.86 & 26.62 & 18.64 & 12.73 & 11.98 & 1.72 & 369.12 & 616.80 & 7.50 & 29.30 & $2.6 \times 10^{5}$ & $1.5 \times 10^{5}$ \\
\hline \multirow[t]{9}{*}{2} & After & 90.92 & 31.67 & 217.07 & 5.71 & 2.05 & 10.73 & 10.21 & 1.52 & 331.73 & 474.33 & 7.37 & 27.74 & $1.3 \times 10^{4}$ & $2.9 \times 10^{3}$ \\
\hline & Efficiency & 40 & 61 & 20 & 79 & 89 & 15 & 13 & - & 10 & 23 & - & 5 & 95 & 98 \\
\hline & $(\%)$ & & & & & & & & & & & & & & \\
\hline & \multicolumn{15}{|l|}{ 2.VFCW-Control } \\
\hline & Before & 151.92 & 79.14 & 271.86 & 26.62 & 18.46 & 12.73 & 11.98 & 1.72 & 369.12 & 616.80 & 7.50 & 29.30 & $1.3 \times 10^{5}$ & $1.4 \times 10^{3}$ \\
\hline & After & 95.92 & 28.20 & 266.53 & 4.00 & 2.10 & 11.10 & 10.21 & 1.50 & 293.67 & 441.60 & 8.50 & 28.98 & $6.0 \times 10^{3}$ & $1.1 \times 10^{3}$ \\
\hline & Efficiency & 36 & 66 & 2 & 85 & 89 & 15 & 15 & - & 20 & 33 & - & 1 & 97 & 99 \\
\hline & \multicolumn{15}{|l|}{$(\%)$} \\
\hline & tandard & 120 & 20 & 3,000 & 100 & 25 & - & - & 4.00 & - & - & 5.5 & 40 & 5,000 & 1,000 \\
\hline
\end{tabular}




\subsection{Pig-Slaughterhouse Wastewater Treatment and VFCW}

According to pig slaughterhouse wastewater is normally contained a lot of organic content in form of chemical oxygen demand (COD) and biological oxygen demand (BOD) which found from the previous researches. In order that statement, the primary experiment was focused on COD concentration in pig slaughterhouse wastewater but BOD excluded because it could be estimated in the range between $40 \%$ to $60 \%$ of COD. Anyway, the DOPC-MONRE (2010)studied on the measurement of COD which contaminated on the ground surface of pig slaughtering areas found in averaged value of $1,426.3 \mathrm{mg} / \mathrm{L}$, higher than standard $120 \mathrm{mg} / \mathrm{L}$ (Table 1). After it was travelled through OP pond 1 with HRT about 2 days, the effluent contained with COD 328.8 $\mathrm{mg} / \mathrm{L}$ that turning to be wastewater treatment efficiency of OP pond 1 about $77 \%$. In consequence, it became OP-pond 2 effluent approximately $151.92 \mathrm{mg} / \mathrm{L}$ (Table 2) and in turn to OP pond 2 efficiency $84 \%$. In case of Oxidation Pond for pig slaughterhouse wastewater treatment was supposed to have only 2 OP ponds, (pond 1+2) the treatment efficiency could be calculated about $96 \%$ as obtained from COD 1,426.3 mg/L before draining into pond 1 and becoming effluent COD $328.8 \mathrm{mg} / \mathrm{L}$, and finally pond 2 effluent COD $151.92 \mathrm{mg} / \mathrm{L}$. (COD standard $120 \mathrm{mg} / \mathrm{L}$ ). Summarily speaking, the treatment efficiency of Oxidation Pond alone cannot be able to decrease the high concentrated COD of pig slaughterhouse wastewater but it really needs another supporting wastewater treatment technology to eliminate the above-standard COD remainders down to satisfactory level.

Besides COD concentration $1,426.30 \mathrm{mg} / \mathrm{L}$ as found on the ground surface of pig slaughtering areas, another water quality indicators were used for making sure before selecting the wastewater treatment to support the OP technology. Anyway, the most popular indicators were used for evaluating the better way on how to take them identifying the accuracy of treatment efficiency of pig slaughterhouse wastewater treatment as informed by Cauillard et al (1989) and Hammer (1989) and Hammer and Bastian (1989), Paltri et al (2011), Pattamapitoon (2013),Hadad et al (2006) andTritt and Schuchardt (1992). For response the previous words, the study will pinpoint on BOD, coliform bacteria, and fecal bacteria as the added indicators for precise hypothesizing the supporting technology for pig slaughterhouse wastewater treatment.

For response previous statement, the second study was paid attention on the quantity and quality of pig slaughterhouse wastewater from the ground surface after passing through OD Pond 1 as called the effluent of OP pond 1, which was found the status of COD $328.80 \mathrm{MPN} / 100 \mathrm{~mL}$, BOD $181.98 \mathrm{mg} / \mathrm{L}$, coliform bacteria $2.1 \mathrm{x}$ $10^{-6} \mathrm{MPN} / 100 \mathrm{~mL}$, and fecal bacteria $1.1 \times 10^{-6}$, while OD pond 2 effluent indicated COD $151.92 \mathrm{mg} / \mathrm{L}$, BOD $79.14 \mathrm{mg} / \mathrm{L}$, coliform bacteria $2.6 \times 10^{-5} \mathrm{MPN} / 100 \mathrm{~mL}$, and fecal bacteria $1.5 \times 10^{-5} \mathrm{MPN} / 100 \mathrm{~mL}$ (see Table2). The existing measured values of four indicators were still higher than standards that existed more contaminants of pig meat, grease, hairs, urine, dunk, and blood in which some of them might be the bacteria inhibitors as described by Cauillard et al (1989) and Hammer (1989) and Hammer and Bastian (1989) Hammer (1989) Pattamapitoon (2013) Hadad et al (2006) and Tritt and Schuchardt (1992). In the same way, Hammer (1989) Pattamapitoon (2013) Hadad et al (2006) Palatsi et al (2011) and Tritt and Schuchardt (1992) concluded that there were uncertain condition to complete the bacterial organic digestion processes, it depends on solar radiation, air temperature, atmospheric moisture, washing water quality, organic properties, bacteria types, and topography. Fortunately, the vertical flow constructed wetlands (VFCW) can eliminate all stated pig organs as found by LERD (1999), Kayser and Hunst (2005), Cui et al (2010), Soroko (2007), Molle et al (2008), Sklarz et al (2009), Tripathi and Shukla (1991), and Ye et al (2001). In principles, wastewater is transferred from point sources on the water surface in VFCW units, then wastewater as treated by bacterial organic digestion processes is sunk to the bottom before penetrating through in order of soils, sand, gravel, and flowing in pipe holes, finally flowing out at ended-pipe part as effluent of VFCW units. For clear understanding, the special was aimed at the relation between COD, BOD, coliform and fecal bacteria in treated wastewater moving out from OD ponds (1 and 2) and VFCW (Typha and Control) units, alternately to COD, BOD, coliform and consideration fecal bacteria in effluent moving out from both VFCW units as shown in Table 2.

\subsection{Role of VFCW for Pig Slaughterhouse Wastewater Treatment}

Special consideration was aimed at the relation between COD, BOD, coliform and fecal bacteria in treated wastewater moving out from OD ponds (1 and 2) and VFCW (Typha and Control) units, alternately to COD, BOD, coliform and fecal bacteria in effluent moving out from both VFCW units as shown in Table2 and described as follows:-

\section{Case1: VFCW-Typha Capacity}

Due to the fact that VFCW-Typha efficiency for retreating the high concentrated COD and BOD effluent from was paid attention on influent from OP ponds 1 and 2 which were needed to convince the failure of this engineering tool being not suited for the pig slaughtering in Thailand. Also, it would be the basic understanding 
to look for the supported technology decreasing COD and BOD content under the standard concentration. The details will be focused on the minimum concentration of COD, BOD, coliform and fecal bacteria rather than efficiency of wastewater treatment capacity.

\section{1) OP Pond 1 Influent Treatment Capacity}

The effluent quality from VFCW-Typha units as obtained treated wastewater from OD pond1 found COD 129.80 $\mathrm{mg} / \mathrm{L}$, BOD $57.67 \mathrm{mg} / \mathrm{L}$, coliform bacteria $2.9 \times 10^{-4} \mathrm{MPN} / 100 \mathrm{~mL}$, and fecal bacteria $2.0 \times 10^{-4} \mathrm{MPN} / 100 \mathrm{~mL}$, in turn of treatment efficiency, COD $59 \%$, BOD $70 \%$, coliform bacteria $96 \%$, and fecal bacteria $98 \%$. (see Table2).

\section{2) OP Pond2 Influent Treatment Capacity}

The effluent quality from VFCW-Typha units as obtained treated wastewater from OD pond2 found COD 90.92 $\mathrm{mg} / \mathrm{L}$, BOD $31.67 \mathrm{mg} / \mathrm{L}$, coliform bacteria $1.5 \times 10^{-4} \mathrm{MPN} / 100 \mathrm{~mL}$, and fecal bacteria $2.9 \times 10^{-3} \mathrm{MPN} / 100 \mathrm{~mL}$, in turn of treatment efficiency, COD $40 \%$, BOD $61 \%$, coliform bacteria $95 \%$, and fecal coliform $98 \%$ (see Table 2).

The findings were satisfied in COD concentration after VFCW-Typha for pig slaughterhouse wastewater treatment in terms of minimum COD $90.92 \mathrm{mg} / \mathrm{L}(120 \mathrm{mg} / \mathrm{L}$ as standard value) from OP pond 2 but opposite from $\mathrm{OP}$ pond 1. In addition, the concentration of BOD, coliform and fecal bacteria were not quite acceptable under standard values. However, the said concentrated COD, BOD, coliform and fecal bacteria effluent from OP ponds 1 and 2 were shown in higher than standard values and the same trend from research results as found by Juwarkar et al (1995), Maine et al (2006), Khan et al (2009), Ahn and Mitsch (2002), Cui et al 2010), Couillard et al (1989), Hosetti and Frost (1995), Soroko (2007), Molle et al (2008), Sklarz et al (2009), Luangsoonton (2010), and Pattamapitoon (2013). So, it is necessary to conclude that not only VFCW-Typha is able to be the supported technology but also OP ponds 1 and 2 have to more than 2 ponds and also enlarging unit size (longer $30 \mathrm{~m}$. and/or wider $3 \mathrm{~m}$.) in order to make sure for lowering COD, BOD, coliform and fecal bacteria in VFCW-Typha effluent down to under standard values.

\section{Case2: VFCW-Control Treatment Capacity}

The effluent quality from VFCW-Control units as obtained treated wastewater from OD pond1 found COD $174.68 \mathrm{mg} / \mathrm{L}$, BOD $51.60 \mathrm{mg} / \mathrm{L}$, coliform bacteria $4.0 \times 10^{-4} \mathrm{MPN} / 100 \mathrm{~mL}$, and fecal bacteria $2.0 \times 10^{-4}$ MPN $/ 100 \mathrm{~mL}$, in turn of treatment efficiency, COD $44 \%$, BOD $66 \%$, coliform bacteria $95 \%$, and fecal bacteria $99 \%$.

The effluent quality from VFCW-Control units as obtained treated wastewater from OD sectional pond 2 found COD $95.92 \mathrm{mg} / \mathrm{L}$, BOD $28.20 \mathrm{mg} / \mathrm{L}$, coliform bacteria $6.0 \times 10^{-3} \mathrm{MPN} / 100 \mathrm{~mL}$, and fecal bacteria $1.1 \times 10^{-3}$ $\mathrm{MPN} / \mathrm{mL}$, in turn of treatment efficiency, COD $36 \%$, BOD $66 \%$, coliform bacteria $97 \%$, and fecal bacteria $99 \%$.

Expectedly, the concentration of COD, BOD, coliform and fecal bacteria in VFCW-Control and VFCW-Typha effluent were the same trend as found from previous research results. Anyway, it is quite obvious that the treatment capacity of VFCW-Control cannot competed against VFCW-Typha because of an increasing oxygen supply as energy for bacterial organic digestion processes to convert organic substances in forms of COD and BOD becoming inorganic materials, but in opposite direction for coliform and fecal bacteria accordance with the digesting bacterial death from solar radiation, especially ultraviolet (Pattamapitoon 2013, Cao and Mehrvar 2011, Kayser 2005, Grosse1989, Mirmov and Belyakava 1982, Nopparatanaporn 1992, Palatri et al 2011).

\section{Case3: VFCW-Typha and VFCW-Control Relations}

Above results are informed that treatment efficiencies between OD ponds 1 and 2 between sectional ponds 1-2 and VFCW (Typha-Control units) have shown in low efficiencies, except coliform and fecal bacteria seemed high but the effluent still higher than standards, as illustrated in Table 2. There is somewhat higher efficient COD and BOD in effluent from VFCW-Typha units than VFCW-Control units but the another water quality indicators were opposite, especially coliform and fecal bacteria (see Table 2). High bacterial organic digestion processing rates in VFCW-Typha were expected to convince such mentioned statement but direct solar energy from sky to the open space of VFCW-Control was surely affected to kill the coliform and fecal bacteria one way or another.

Close observation on the Tables 1 and 2 found that theanother effluent quality indicators,i.e. TDS, EC, alkalinity, and $\mathrm{pH}$ were under standard values except $\mathrm{DO}$ was opposite. When the chemical analysis of slaughterhouse wastewater was taken in consideration, this experiment did not extract ammonia-nitrogen, total P, Ortho P, coliform and fecal bacteria which plays vital role in contamination from pig slaughtering and dissecting activities 
and also for phytoremediation by Typha growth in vertical flow constructed wetlands. Therefore, they must be included the in-depth study on VFCW application for second treatment of OD effluent which were identified as too high concentrated COD and BOD effluent.

\subsection{VFCW-Typha for Supporting OD Effluent Treatment}

In principles, the VFCW units would be functioned like "value added technology" for second treatment of OD effluent for feasibility study by using only the OD ponds 1 and 2 . In operational point of view, the daily amount of slaughterhouse wastewater is not only small quantity but also discontinuity flow from OD ponds 1 to 2,3 , and 4. This would be the reason of having a small part of inflow than OD storage capacity with stagnation conditioning as well as high evaporation rate all four sectional ponds on daytime, especially in wet season of the year. However, the previous scientific observation indicated that the decreasing organic wastes by bacterial organic digestion was relied on the oxygen supplying from both the photosynthesis of algae and thermo-siphon processing as caused by OD water surface evaporation process (Mirmov and Belyakava 1982, Deubigh and Raumann 1952, Poommai et al 2013, Grofse and Bauch 1991,Grosse 1989, Ameth and Stichimair 2001 ,Bearman 1957). Moreover, there was no existing submerged aquatic plants and less phytoplankton in turbid OD wastewater to produce the oxygen as energy supplying for bacterial organic digestion process. This would be another reason why the OD effluent found COD, BOD, and DO out of standards. Inevitably, the wastewater quality indicators of ammonia-nitrogen, total $\mathrm{P}$, and Ortho $\mathrm{P}$ have to add up for gaining in-depth knowledge (Hammer 1989, Hammer and Bustian 1989, Jenssenet al 1993, Maine et al 2006, Mackey and Smail 1995)

\subsection{Typha Useful Life for Pig Slaughterhouse Wastewater Treatment}

Typha (Typhaangustifolia Linn.), cattail as common name, is classified as emergent aquatic plant which has aerenchyma cells (spongy cells) in leaf, especially very young leaf which allows the photosynthesizing oxygen going through its soft membrane to form rhizosphere around rhizomes before diffusing to bacteria in soils and wastewater as energy supplying for bacterial organic digestion processing as seen phenomena in Table 2 . Accordance with previous saying, why the treatment efficiency of VFCW-Typha units looked better than VFCW-Control because of nature-by-nature processes through the thermo-osmosis techniques to supply oxygen from rhizosphere to supply energy for bacterial organic digestion until coming an end of typha useful life.

Naturally, wetland is supposed to be the balancing unit area among soils and its properties, organic wastes in wastewater, microorganisms, oxygen as energy supplying for bacterial organic digestion, aquatic plants and up-taking nutrient capacity as well as its toxic-chemical accumulative organs (Tripathi and Shukla 1991, Reddy et al 1991, Reddy et al 1990, Hadad et al 2006, Xia and Ma 2006). Therefore, an applicable VFCW-Typha for pig slaughterhouse wastewater is subjected to pay attention to convert the organic matters to become inorganic materials as plenty nutrients for typha growing, such as $\mathrm{P} 236$ to $417 \mathrm{ppm}$ and $\mathrm{N} 1.033$ to $1,500 \mathrm{ppm}$ after flooding OP pond1; and P 243 to $412 \mathrm{ppm}$ and N 833 to 1,367 ppm after flooding OP pond2 (Table3). At the same time, the growing Typha are able to up-take toxic-chemicals to accumulate in all parts of its organs in order to maintain the constructed wetland in balancing stage. According to treat wastewater along with continuous flowing, Typha species as the aquatic plants have to be trimmed at useful age (Figure4) above submerged soil surface at full-water level in order to provide the new rhizome budding for supplying oxygen by photosynthesis and thermo-osmosis processes; and also to keep nutrient balance of constructed wetlands (Reddy et al 1990, Ye et al 2001, Xia and Ma 2006, Hadad et al 2006, Trpathi and Shukla 1991).

Table 3. Plant nutrient accumulation in soils and Typha leaves above ground and also including biomass and average height of Typha for pig slaughterhouse wastewater treatment

\begin{tabular}{|c|c|c|c|c|c|c|c|}
\hline \multirow[t]{2}{*}{ No. } & \multirow{2}{*}{\multicolumn{2}{|c|}{ Items }} & \multicolumn{2}{|c|}{ Nutrients } & \multirow[t]{2}{*}{ weeks } & \multicolumn{2}{|c|}{ Average Height (cm.) } \\
\hline & & & Sect.Pond1 & Sect.Pond2 & & Sect.Pond1 & Sect.Pond2 \\
\hline 1 & Bion & lass, $\mathrm{kg} / \mathrm{m}^{2}$ & 0.44 & 0.28 & 1 & 111 & 109 \\
\hline \multirow[t]{7}{*}{2} & $\mathrm{P}$ in & oils, ppm & & & 2 & 147 & 147 \\
\hline & 1.VF & CW-Typha & & & 3 & 182 & 169 \\
\hline & 1) & Before & 236 & 243 & 4 & 199 & 188 \\
\hline & 2) & After & 417 & 412 & 5 & 223 & 211 \\
\hline & $2 . \mathrm{VF}$ & CW-Control & & & 6 & 241 & 224 \\
\hline & 1) & Before & 348 & 312 & 7 & 262 & 244 \\
\hline & 2) & After & 415 & 407 & 8 & 271 & 252 \\
\hline
\end{tabular}




\begin{tabular}{|c|c|c|c|c|c|c|c|}
\hline \multirow[t]{7}{*}{3} & \multicolumn{4}{|c|}{$\mathrm{N}$ in Soils, $\mathrm{ppm}$} & 9 & 283 & 261 \\
\hline & \multicolumn{4}{|c|}{ 1.VFCW-Typha } & 10 & 287 & 270 \\
\hline & 1) & Before & 1033 & 967 & 11 & 294 & 279 \\
\hline & 2) & After & 1500 & 1367 & 12 & 294 & 283 \\
\hline & \multicolumn{7}{|c|}{ 2.VFCW-Control } \\
\hline & 1) & Before & 1100 & 833 & & & \\
\hline & 2) & After & 1400 & 1300 & & & \\
\hline
\end{tabular}

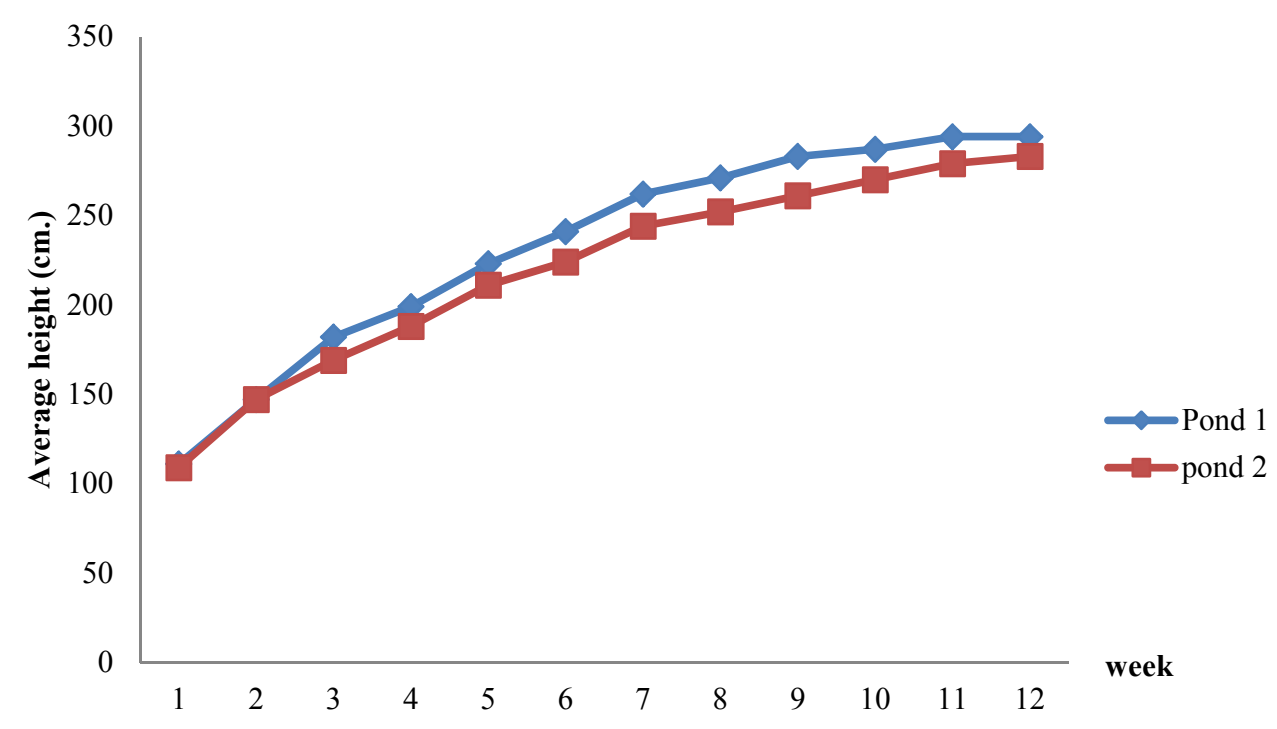

Figure 4. Average height for useful age determination as the maximum treatment of pig slaughterhouse wastewater in relation to flowering of Typha growing in vertical flow constructed wetlands

\subsection{VFCW-Typha Treatment Modification}

Previous findings learnt that the high concentration of organic matters as contaminated in pig slaughterhouse wastewater from activities of pig slaughtering and dissecting cannot be well treated good enough by OP engineering tool (ponds 1 and 2) in pond size of 3-m width, 30-m length and 5-m depth. Principally, the completeness of bacterial organic digestion process is really needed the longer HRT (hydraulic retention time) in order to have more time to convert the organic forms into the inorganic materials as indicated by LERD (1999) research on HRT 21 days with 5-consecutive oxidation ponds that would be enough to complete the bacterial digestion processing. Therefore,It is impossible to take the pig slaughterhouse 4-consecutive Oxidation Ponds with only 12-day HRT to complete such sophisticated processing. For future study, it is recommended to use the 4-consecutive Oxidation Ponds not to replace the old ones but it should evacuate the sludge in order to encourage the bacterial organic digestion process for effective reduction of COD, BOD, $\mathrm{P}, \mathrm{N}$, etc.

At the same procedure, the VFCW-Typha unit size of 3-m width, 30-m length, and 1-m depth is not enough size to obtain the bacterial organic digestion completeness for alternating 5-day stagnating and another 2-day releasing to out sources. Looking at the research results from effluent quality after passing through both the VFCW-Typha and VFCW-Control found that the COD and BOD values were lower than findings from Oxidation Ponds but all of them were still over standards. It is foreseen under research results of LERD (1999) that if the VFCW length were prolonged the HRT instead of 30 meters to 40 meters, the concentrated COD, BOD and another indicators would become under standard values. If the experimental areas are not enough to prolong up to 40-m length, the prolongation of 3-m width to become 4-m or 5-m width would be enough to solve the ineffectiveness of pig slaughterhouse wastewater treatment by 4-consecutive Oxidation Ponds in cooperating with vertical-flow constructed wetlands with the size of 4-m wide, 40-m long, and 1-m deep vertical-flow constructed wetlands which is integrated for pig slaughterhouse wastewater treatment from previous papers by Stottmister et al (2003), Borja et al (1998), Grosse (1989), Grofse and Bauch (1991), Deubigh and Raumann (1952), Jenssen et al (1993), Hammer (1989), Ahn and Mitsch (2002), Cui et al (2010), Boyd (1970), Khan et al (2009), Juwarkar et al 1995), Borkar and Mahatma (2011), Maine et al (2006), Keddy (2010), Ramsey et al 
(2013), Hosetti and Frost (1995), Noparatanaporn (1992), Mackey and Smail (1995), and LERD (1999).

\section{Conclusion}

Due to Oxidation Pond (OP) as engineering tool is generally used for pig slaughterhouse wastewater treatment that containing high concentrated COD and BOD in effluent but it becomes point sources of stream pollution in concerned areas. For problem solving, the vertical-flow constructed wetland (VFCW) was proposed for increasing effectiveness in effluent retreating on excess organic pollutants. The experiment was focused on high concentrated COD and BOD effluent from OP ponds 1 and 2 as the influent of 2 sets of VFCW units, each set containing 3-units of VFCW-Typha plus 1-unit of VFCW-Control. The high COD and BOD content effluent as obtained from OP ponds1 and 2 were taken in the VFCW-Typha and VFCW-Control units for conditioning the alternative 5-day stagnation and 2-day before releasing to the public water sources. The results found as follows:

In primary study, the pig slaughterhouse wastewater samples on the ground floor were taken before draining into Oxidation Pond as the point sources and found COD 1,426.3 mg/L and still above standard after treating by the 2-consecutive oxidation ponds. Moreover, the secondary experimental study found COD $151.92 \mathrm{mg} / \mathrm{L}$, BOD $79.14 \mathrm{mg} / \mathrm{L}$, and coliform bacteria $2.6 \times 10^{-5} \mathrm{MPN} / 100 \mathrm{~mL}$. They were above the standard values that needed the VFCW-Typha units for decreasing all excess organic forms. After treating the effluent by VFCW-Typha from the 2-consecutive oxidation ponds, the results found COD $90.92 \mathrm{mg} / \mathrm{L}$, BOD $31.67 \mathrm{mg} / \mathrm{L}$ and coliform bacteria $1.5 \mathrm{x}$ $10^{-4} \mathrm{MPN} / 100 \mathrm{~mL}$ which were almost above the standard values. Furthermore, the VFCW-Control units cannot compete against VFCW-Typha.

\section{References}

Ahn, C., \& Mitsch, W. J. (2002). Evaluating the use of recycled coal combustion products in constructed wetland: an ecologic-economic modeling approach. Ecological Modeling, 150, 117-140. http://dx.doi.org/10.1016/s0304-3800(01)00477-x

Ameth, S., \& Stichimair, J. (2001). Characteristics of thermo-siphon rebillers. International Journal of Thermal Sciences, 40, 385-391. http://dx.doi.org/10.1016/s1290-0729(01)01231-5

APHA, AWWA, WEF. (2005). Standard Methods for the Examination of Water and Wastewater. second edition, American Public Health Association, Washington, USA, 523 p.

Bearman, R. J. (1957). The thermo-osmosis of rare grass through a rubber membrane. Journal of Physical Chemistry, 61, 708-714.

Berkun, M. (2005). Effects of Ni, Cr, $\mathrm{Hg}, \mathrm{Cu}, \mathrm{Zn}, \mathrm{Al}$ on the dissolved oxygen balance of streams. Chemosphere, 59, 207-215. http://dx.doi.org/10.1016/j.chemosphere.2004.11.086

Black, C. A., Evans, D. D., Ensminger, J. L., \& Clark, F. F. (1965). Method of Soil Analysis. American Society of Agronomy, Inc., New York, $521 \mathrm{p}$.

Borja, R. (1995). Effect of organic loading rate on anaerobic treatment of slaughterhouse wastewater in a $\begin{array}{lllll}\text { fluidized-bed } \quad \text { reactor. } & \text { Bioresource, } & \text { Technology, } & 52, & \text { 157-162. }\end{array}$ http://dx.doi.org/10.1016/0960-8524(95)00017-9

Borja, R., Banks, C. J., Wang, Z., \& Mancha, A. (1998). Anaerobic digestion of slaughterhouse wastewater usinga combination sludge blanket and filter arrangement in a single reactor. Bioresource Technology, 68, 125-133. http://dx.doi.org/10.1016/s0960-8524(98)00004-2

Borkar, R. P., \& Mahatma, P. S. (2011). Wastewater treatment with vertical flow constructed wetland. International Journal of Environmental Science, 2, 590-603.

Boyd, C. E. (1970). Vascular aquatic plants for mineral nutrient removal from polluted water. Economic Botany, 2444, 94-103.

Cao, W., \& Mehrvar, M. (2011). Slaughterhouse wastewater treatment by combined anaerobic baffled reactor and $\mathrm{UV} / \mathrm{H} 2 \mathrm{O}$ processes. Chemical Engineering Research and design. Chemical Engineering Research and Design, 89, 1139-1143. http://dx.doi.org/10.1016/j.cherd.2010.12.001

Cauillard, D., Gariepy, S., \& Tran, F. T. (1989). Slaughterhouse effluent treatment by thermophilic aerobic process. Water Research, 23, 573-579. http://dx.doi.org/10.1016/0043-1354(89)90024-9

Cui, L. H., Ouyang, Y. Q., Lou, F., Yang, L., Chen, Y., Zhu, W. L., \& Luo, S. M. (2010). Removal of nutrients from wastewater with Canna indica L. under different vertical flow constructed wetland conditions. Ecological Engineering, 36, 1083-1088. http://dx.doi.org/10.1016/j.ecoleng.2010.04.026 
Deubigh, K. G., \& Raumann, G. (1952). The thermo-osmosis of gas through a membrane.II. Experimental Proceeding of Royal Science, 21(A), 518-533.

DIW-MOI. (1996). Handbook of Environmental Management for Slaughterhouse. Department of Industrial Works, Ministry of Industry, p. 190.

DOPC-MONRE. (2010). Annual Report on Existing Pollution in Thailand. Department of Pollution Control, Ministry of Natural Resources and Environment, Bangkok Thailand, p. 158.

Faerge, J., Magid, J., \& de Vries, F. T. P. (2001). Urban nutrient balance for Bangkok. Ecological Modeling, 139, 63-74. http://dx.doi.org/10.1016/s0304-3800(01)00233-2

Faulkner, H., Edmonds-Brown, V., \& Green, (2000). Problems of quality designation in diffusely polluted urban streams--the case of Pymme's Brook, north London. Environmental Pollution, 109, 91-107. http://dx.doi.org/10.1016/s0269-7491(99)00227-4

Grofse, W., \& Bauch, B. (1991). Gas transfer in floating-leaved plants. Plant Physiology, 97, 185-192. http://dx.doi.org/10.1007/BF00035391

Grosse, W. (1989). Thermo-osmosis air transport in aquatic plants affecting growth activities and oxygen diffusion to wetland soils: In Constructed Wetland for Wastewater Treatment. Edited by D.A. Hammer, Lewis Publishers, Inc., Chelsea, p.469-478.

Hadad, H. R., Maine, M. A., \& Bonetto, A. (2006). Macrophyte growth in a plot-scale constructed wetland for

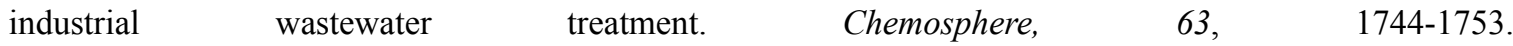
http://dx.doi.org/10.1016/j.chemosphere.2005.09.014

Hammer, D. A. (1989). Constructed Wetlands for Wastewater Treatment -- Municipal, Industrial, Agricultural. Lewis Publishers, Inc., Chelsea, Michigan, 831 p.

Hammer, D. A., \& Bastian, R. K. (1989). Wetland ecosystem: Natural Water Purifiers: In Constructed Wetland for Wastewater Treatment. Lewis Publishers, Michigan, $485 \mathrm{p}$.

Hosetti, B. B., \& Frost, S. (1995). A review of the sustainable value of effluents and sludges from wastewater stabilization ponds. Ecological Engineering, 5, 421-431. http://dx.doi.org/10.1016/0925-8574(95)00005-4

Jenssen, P., Maehlum, T., \& Krogstad, T. (1993). Potential use of constructed wetlands for wastewater treatment in northern Argentina environments. Water Science and Technology, 28, 149-157.

Juwarkar, A. S., Oke, B., Juwarkar, A., \& Patnaik, S. M. (1995). Domestic wastewater treatment through constructed wetland in India. Water Science and Technology, 32, 291-294. http://dx.doi.org/10.1016/0237-1223(95)00637-0

Kayser, K., \& Hunst, S. (2005). Processes in vertical flow reed beds: nitrification, oxygen transfer and soil clogging. Water Science and Technology, 51, 177-184.

Keddy, P. A. (2010). Wetland Ecology: Principles and Conservation. Second Edition, Cambridge University Press, Cambridge, UK, 497 p.

Khan, S., Ahmed, I., Shah, M. T., Rehman, S., \& Khaliq, A. (2009). Use of constructed wetland for the removal of heavy metals from industrial wastewater. Journal of Environmental Management, 90, 3451-3457. http://dx.doi.org/10.1016/j.jenvman.2009.05.026

LERD. (1999). Economized Technology for Community Garbage Disposal and Wastewater Treatment by Aquatic Plants. The King's ainitiative Laem Phak Bia Environmental Studies, Research and Development Project at Laem Phak Bia Sub-District, Ban Laem District, Petchaburi Province. Thailand, $420 \mathrm{p}$.

LERD. (2000). Science for Garbage Disposal and Wastewater Treatment towards the King's Initiative Project. Technical Papers for 10-Year LERD Seminar, Organized by ChaipatanaFoundation, during 24-25 August 2000 at Kasersart University. Bangkok Thailand, 560 p.

LERD. (2012). Annual Report on The King's Royally Initiated LaemPhak Bia sub-district, Ban Laem district, Petchaburi province Thailand. (serialnumbers of 2005 to 2011), $86 \mathrm{p}$.

Luangsoonton, S. (2010). Growth and wastewater treatment in Suphanburi municipal slaughterhouse wastewater.M.S. Thesis, College of Environment, Kasetsart University. Bangkok Thailand, 82 p.

Mackey, A. P., \& Smail, G. (1995). Spatial and temporal variation in litter fall of Avicennia marina (Forssk) Vierh.in the Brisbane river, Queensland, Australia. Aquatic Botany, 133-142. http://dx.doi.org/10.1016/0304-3770(95)00490-Q 
Maine, M. A., Sune, N., Hadad, H., Sanchez, G., \& Bonetto, C. (2006). Nutrient and metal removal in a constructed wetland for wastewater treatment from a metallurgic industry. Ecological Engineering, 26, 341-347. http://dx.doi.org/10.1016/j.ecoleng.2005.12.004

Masse, D. I., \& Masse, L. (2000a). Treatment of slaughterhouse wastewater in aerobic sequencing batch reactors. Canadian AgriculturalEngineering, 42, 131-137.

Masse, D. I., \& Masse, L. (2000b). Characterization of wastewater from hog slaughterhouse in Eastern Canada and evaluation of their in-plant wastewater treatment systems. Canadian Agricultural Engineering, 42, 139-146.

Metcalf \& Eddy (1979). Wastewater Engineering: treatment, disposal, reuse. Second Edition, McGraw-Hill, New York, $542 \mathrm{p}$.

Mirmov, N. I., \& Beyakava, I. G. (1982). Heat liberation during vapor condensation in a thermo-siphon. Journal of Engineering Physics, 43, 970-974.

Molle, P., Prost-Boucle, S., \& Lienard, A. (2008). Potential for total nitrogen removal by combining vertical flow and horizontal flow constructed wetlands: an full-scale experiment study. Ecological Engineering, 34, 23-29. http://dx.doi.org/10.1016/j.ecoleng.2008.05.016

MOPH. (1998). Technical Guidelines for Environmental Management of slaughterhouse in 1998. Ministry of Public Health, $210 \mathrm{p}$.

Nopparatanaporn, N. (1992). Microorganisms in Wastewater.Department of Microbiology, Faculty of Science, Kasetsart University, Bangkok Thailand, 412 p.

Othman, I., Amar, A. N., Rosman, Z. N. H., Harun, H., \& Chelliapan, S. (2013). Livestock wastewater treatment using aerobic granular sludge. Bioresource Technology, 133, 630-634. http://dx.doi.org/10.1016/j.biortech.2013.01.149

Padgett, W. J. (1975). A stochastic model for stream pollution. Mathematical Biosciences, 25, 309-317. http://dx.doi.org/10.1016/0025-5564(75)90008-5

Palatri, J., Vinas, M., Guivernau, M., Fermandez, B., \& Flotsi, X. (2011). Anaerobic digestion of slaughterhouse waste: main process limitation and microbial community interactions. Bioresource Technology, 102, 2219-2227. http://dx.doi.org/10.1016/j.biortech.2010.09.121

Pattamapitoon, T. (2013). Natural phenomena of solar radiation to reduce coliform and pathogenic bacteria of oxidation ponds for wastewater treatment system.Ph.D. Thesis, Graduate School, Kasetsart University, Bangkok Thailand, 75 p.

Poommai, S., Chunkao, K., Dumpin, N., Boonmang, S., \& Nimpee, C. (2013). Determining the in-pipe anaerobic processing distance before draining to oxidation pond of municipal wastewater treatment. International Journal of Environmental Science and Development, 4, 157-162. http://dx.doi.org/10.7763/IJESD.2013.V4.326

Ramsey, D., Soldevila-Lafon, V., \& Viladomiv, L. (2013). Environmental regulations in the hog farming section: A comparison of Catalonia, Spain and Manitoba, Canada. Land Use Policy, 32, 239-249. http://dx.doi.org/10.1016/j.landusepol.2012.10.020

Reddy, K. R., Agami, M., \& Tucker, J. C. (1990). Influence of phosphorus on growth and nutrient storage by water hyacinth (Eichhornia crassipes (Mart.)Solms) plants. AquaticBotany, 37, 355-365. http://dx.doi.org/10.1016/0304-3770(90)90021-c

Reddy, K. R., Agami, M., \& Tucker, J. C. (1991). Influence of potassium supply on growth and nutrient storage by water hyacinth. Bioresource Technology, 37, 79-81. http://dx.doi.org/10.1016/0960-8524

Sklarz, M. Y., Gross, A., Yakirevich, A., \& Soasres, M. I. M. (2009). A recirculating vertical flow constructed wetland for the treatment of domestic wastewater. Desalination, 246, 617-624. http://dx.doi.org/10.1016/j.desal.2008.09.002

Soroko, M. (2007). Treatment of wastewater from small slaughterhouse in hybrid constructed wetland systems. Eco-Hydrology and Hydrology, 7, 339-343. http://dx.doi.org/10.1016/s1642-3593(07)70117-9

Stottmeister, U., Wiebner, A., Kuschk, P., \& Kappelmeyer, U. (2003). Effects of plants and microorganisms in constructed wetlands for wastewater treatment. Biotechnology Advances, 22, 93-117. http://dx.doi.org/10.1016/j.biotechadv.2003.08.010 
Streeter, H. W., \& Phelps, E. B. (1925). A study of the pollution and natural purification of the Ohio River. US Public Health Service. Bulletin Number, 146, 96.

Suchkov, N., Darakas, E., \& Ganoulis, J. (2010). Phytoremediation as a prospective method for rehabilitation of areas contaminated by long-term sewage sludge storage: A Ukrainian-Greek case study. Ecological Engineering, 36, 373-378. http://dx.doi.org/10.1016/j.ecoleng.2009.11.002

Tripathi, B. D., \& Shukla, S. C. (1991). Biological treatment of wastewater by selected aquatic plants. Environmental Pollution, 69, 69-78. http://dx.doi.org/10.1016/0269-7491(91)90164-R

Tritt, W. P., \& Schuchard, F. (1992). Materials flow and possibilities of treating liquid and solid wastes from slaughterhouses in Germany. Bioresources Technology, 41, 235-245. http://dx.doi.org/10.1016/0960-8524(92)90008-L

Tyagi, B., Gakkhar, S., \& Bhargava, D. S. (1999). Mathematical modelling of stream DO-BOD accounting for settleable BOD and periodically varying BOD sources. Environmental Modelling and Software, 14, 461-471. http://dx.doi.org/10.1016/S1364-8152(98)00091-7

Xia, H., \& Ma, X. (2006). Phytoremediation of ethion by water hyacinth fromwater. Bioresource Technology, 97, 1050-1054. http://dx.doi.org/10.1016/j.biortech.2005.04.039

Ye, J., Wang, L., Li, D., Han, W., \& Ye, C. (2012). Vertical oxygen distribution trend and oxygen source analysis for vertical flow constructed wetlands treating domestic wastewater. Ecological Engineering, 41, 8-12. http://dx.doi.org/10.1016/j.ecoleng.2011.12.015

Ye, Y., Nora, F., Tam, Y., \& Wong, Y. S. (2001). Livestock wastewater treatment by amangrove pot-cultivation system and the effect of salinity on the nutrient removal efficiency. Marine Pollution Bulletin, 42, 513-521.

\section{Copyrights}

Copyright for this article is retained by the author(s), with first publication rights granted to the journal.

This is an open-access article distributed under the terms and conditions of the Creative Commons Attribution license (http://creativecommons.org/licenses/by/3.0/). 